\title{
PHYSICOCHEMICAL CHARACTERISTICS, ANTIOXIDANT CAPACITY AND PHENOLIC COMPOUNDS OF TOMATOES FERTIGATED WITH DIFFERENT NITROGEN RATES ${ }^{1}$
}

\author{
MARCOS FILGUEIRAS JORGE ${ }^{2}$, KAMILA DE OLIVEIRA DO NASCIMENTO ${ }^{3}$, JOSÉ LUCENA BARBOSA \\ JUNIOR $^{3}$, LEONARDO DUARTE BATISTA DA SILVA ${ }^{2}$, MARIA IVONE MARTINS JACINTHO BARBOSA ${ }^{3 *}$
}

\begin{abstract}
The objective of this work was to evaluate the physicochemical and microbiological characteristics, antioxidant capacity and phenolic compounds of organic cherry tomatoes grown under fertigation with organic dairy cattle wastewater $(\mathrm{DCW})$ with different nitrogen rates. Tomato plants, grown in an agroecological farm in Seropédica, State of Rio de Janeiro, Brazil, were subjected to four different nitrogen rates $(\mathrm{T} 1=0, \mathrm{~T} 2=50, \mathrm{~T} 3=100$ and $\mathrm{T} 4=150 \%$ of $\mathrm{N})$. The moisture, lipids, ashes, protein and total fiber contents, soluble solids ( $\left.{ }^{\circ} \mathrm{Brix}\right)$, reducing and total sugars $(\%), \mathrm{pH}$ and total titratable acidity (mg NaOH per $\left.100 \mathrm{~g}\right)$ were evaluated. The total phenolic content (TPC) and the antioxidant capacity was determined by the DPPH and FRAP methods. The different nitrogen rates $(\% \mathrm{~N})$ affected the $\mathrm{pH}$, protein and soluble solids contents. The increase in $\% \mathrm{~N}$ increased the antioxidant capacities, according to the DPPH assay, and TPC. On the other hand, the tomatoes under fertigation with the highest $\% \mathrm{~N}$ presented lower antioxidant capacities according to the FRAP assay. The fertigation did not affect the microbiological characteristics of the tomatoes, which presented fecal coliforms count $<3 \mathrm{NMP} \mathrm{g}^{-1}$ and absence of Salmonella in $25 \mathrm{~g}$.
\end{abstract}

Keywords: Fertirrigation. Physicochemical composition. Solanum lycopersicum L..

\section{CARACTERÍSTICAS FÍSICO-QUÍMICAS, CAPACIDADE ANTIOXIDANTE E COMPOSTOS FENÓLICOS TOTAIS DE TOMATES FERTIRRIGADOS COM DIFERENTES DOSES DE NITROGÊNIO}

\begin{abstract}
RESUMO - O objetivo deste trabalho foi avaliar a capacidade antioxidante e a qualidade fisicoquímica e microbiológica de tomates cereja orgânicos cultivados com diferentes teores de nitrogênio (\%N) utilizando águas residuárias da bovinocultura. As amostras de tomate foram obtidas na Fazendinha Agroecológica (SIPA Seropédica, RJ) e submetidas a quatro diferentes tratamentos de acordo com os níveis de nitrogênio $(\mathrm{T} 1=0$, $\mathrm{T} 2=50, \mathrm{~T} 3=100$ e $\mathrm{T} 4=150 \% \mathrm{~N})$. Foram determinadas a umidade, teores de cinzas, lipídeos, proteínas e fibras totais. Além do $\mathrm{pH}$, sólidos solúveis ( $\left.{ }^{\circ} \mathrm{Brix}\right)$, açúcares totais e redutores $(\%)$; e acidez titulável $(\mathrm{mg}$ de $\mathrm{NaOH}$ por $100 \mathrm{~g}$ ). O teor de compostos fenólicos e a capacidade antioxidante das amostras (DPPH e FRAP) foram avaliadas. Os diferentes $\% \mathrm{~N}$ afetaram o $\mathrm{pH}$ e o conteúdo de proteínas e sólidos solúveis totais dos tomates. Elevados teores de nitrogênio forneceram amostras com maiores capacidades antioxidantes (método DPPH) e compostos fenólicos. Em contrapartida, obtiveram-se as menores capacidades antioxidantes segundo o método FRAP nas amostras fertirrigadas com altos teores de nitrogênio. A fertirrigação não influenciou significativamente a qualidade microbiológica das amostras estudadas, que apresentaram contagem de coliformes fecaist $<3 \mathrm{NMP} / \mathrm{g}$ e ausência de Salmonella em $25 \mathrm{~g}$.
\end{abstract}

Palavras-chave: Fertirrigação. Composição físico-química. Solanum lycopersicum L..

\footnotetext{
*Corresponding author

${ }^{1}$ Received for publication in 07/30/2015; accepted in 08/17/2016.

Paper produced by partnership between the Science, Technology and Agriculture Innovation Graduate Program; and Food Science and Technology Graduate Program.

${ }^{2}$ Science, Technology and Agriculture Innovation Graduate Program, Agronomy Institute, Universidade Federal Rural do Rio de Janeiro, Seropédica, RJ, Brazil; filgueiras jorge marcos@hotmail.com, monitoreambiental@gmail.com.

${ }^{3}$ Food Science and Technology Graduate Program, Technology Institute, Universidade Federal Rural do Rio de Janeiro, Seropédica RJ, Brazil; kamila.nascimento@yahoo.com.br, lucenadta@gmail.com,mivone@gmail.com.
} 


\section{INTRODUCTION}

Tomato (Lycopersicon esculentum (L.) Miller) is a ubiquitous and highly important vegetable crop around the world, whose fruits are widely consumed and are a source of vitamin $\mathrm{C}$, carotenoids, folate, and potassium, and other antioxidant compounds. It plays an important role in human health as a rich source of lycopene, which is used for cancer treatments. Tomato fruits are cultivated in fields or greenhouses (FERRARI et al., 2008; ALDRICH et al., 2010; ABDEL-MONAIM et al., 2012; LIU et al., 2014; SINGH et al., 2014).

According to the FAO, Brazil was the world's ninth largest tomato producer in 2010, with a production of $4,114,310 \mathrm{Mg}$ (FAOSTAT, 2012). Cherry tomatoes are known by their sensorial properties, excellent flavor and attractive and uniform red color. The production of cherry tomatoes in the State of Rio de Janeiro is mainly conducted by small producers and in family farming areas (ROCHA et al., 2009).

According to European Commission Regulation, organic plant products are those produced without the use of synthetic chemical substances and highly soluble fertilizers. In Brazil, the organic system of agricultural production is defined by the use of specific techniques that optimize the natural resources and improve socio-economic systems, taking into account the cultural integrity of rural communities, aiming the economic and ecological sustainability (CARBONARO et al., 2002; BRASIL, 2003; LIU et al., 2014).

The interest in organic food has been increasing since 1990, because of the awareness of consumers regarding the importance of fruits and vegetables in healthy diets. Organic foods have become one of the fastest-growing food categories, with sales increasing nearly $20 \%$ each year since 1990 (ALDRICH et al., 2010).

Tomato production under organic system has been considered a lucrative opportunity for producers. Therefore, many conventional farmers have adopted the organic system (ALVES et al., 2004). However, few options of genotypes were developed for this system, even for the traditional growing areas, which require selection of genotypes that adapt to the organic system (SILVA et al., 2011; LIU et al. 2014).

The intensive use of chemical fertilizers and pesticides generated environmental problems and increased production costs. However, these problems generated an increased interest in sustainable agricultural practices, which can reduce input costs (CHAUHAN et al, 2015). According to Liao et al. (2015), the use of degraded soils (nutrient-poor surfaces, unstable aggregates, high density, low porosity, and slow infiltration) is a major environmental factor that limits plant growth and productivity. This limitation is found mainly in arid and semi-arid areas, due to the low precipitation and intensive land use in these areas.

The effectiveness of several agricultural fertilization practices for soil improvement has been studied, aiming to overcome these problems. The increase of soil organic matter content, by adding organic compounds has proven to be a valuable practice for maintaining or restoring the soil quality. Moreover, practices used in the organic system are related to higher productivity of plants, especially to those that are rich in active substances used as antioxidants (BORGUINI et al., 2013; CHAUHAN et al., 2015; LIAO et al., 2015; AGRAWAL; SINGH, 2013).

Manure applications have beneficial impacts on soil fertility and physicochemical characteristics of food products in the organic system (CHRISTOU et al., 2014). Nkoa (2014) evaluated the application of solid waste compost (SWC) for reducing the effects of saline water, during the growing of a halophyte grass, and found that the use of SWC improved the nutrient availability, plant growth, rate respiration, photosynthesis, and chlorophyll content. Other authors reported higher antioxidant capacities and polyphenol and flavonoid contents in fruits produced in the organic compared with conventional system (BORGUINI et al., 2013; FIGÀS et al., 2015).

Moreover, consumers pay more for high nutritional value products, that are grown locally, using organic production practices. Therefore, the physical and chemical analysis of these products is important as the organic production certifications for these producers (ALDRICH et al., 2010). Despite the great number of papers about organic agriculture, little information on the effect of nitrogen rates on physiochemical, nutritional and microbiological properties of organic tomatoes is found in the literature. Thus, the objective of this work was to evaluate the physicochemical and microbiological characteristics, antioxidant capacity and phenolic compounds of organic cherry tomatoes grown under fertigation with organic dairy cattle wastewater (DCW) with different nitrogen rates.

\section{MATERIAL AND METHODS}

\section{Samples}

Organic tomatoes (Lycopersicon esculentum (L.) Miller) from the Rio de Janeiro State Agricultural Research Corporation (PESAGRO-Rio), Seropédica $\left(22^{\circ} 48^{\prime} 00^{\prime \prime} \mathrm{S}, 43^{\circ} 41^{\prime} 00^{\prime \prime} \mathrm{W}\right.$ and altitude of 33 meters) were cultivated with dairy cattle wastewater (DCW) from the Agroecological Farm of the Integrated System of Agroecological Production (SIPA) in Seropédica, State of Rio de Janeiro, Brazil. The SIPA is the result of a partnership between the 
Brazilian Agricultural Research Corporation (EMBRAPA), Rio de Janeiro Federal Rural University (UFRRJ) and the PESAGRO-Rio.

\section{Tomato cultivation}

The cultivation was conducted in 12-L pots with a homogeneous soil mixed with a commercial substrate, as a soil conditioner, and an organic compound derived from a sugar cane residue compost processed with millipedes. The soil acidity and fertility was corrected with dolomitic limestone (TNP 95.0\%), thermophosphate $\left(\begin{array}{lll}16.5 \% & \mathrm{P}_{2} \mathrm{O}_{5}\end{array}\right)$ and potassium sulphate $\left(50.0 \% \mathrm{~K}_{2} \mathrm{O}\right)$.

The drainage system of de pots consisted of a 3-cm crushed stone, a geotextile layer (Bidim $\left.{ }^{\circledR}\right)$ and soil. After transplanting the tomato seedlings, the pots were saturated to the field capacity.

The experiment was conducted in a completely randomized design with eight replicates. Four plants were used in each treatment, totaling 32 plants per treatment. The organic dairy cattle wastewater (DCW) $(85 \%$ of well water and $15 \%$ of fresh manure) was prepared every week, aiming to reach characteristics similar to those presented by Erthal et al. (2010). Four different treatments, according to $\mathrm{N}$ rates (Table 1), were applied to the plants. The $\mathrm{N}$ rates were determined after the fresh manure dilution in water, which were adjusted to $0 \%$ (T1), 50\% (T2), 100\% (T3), and 150\% (T4) of the recommended $\mathrm{N}$. The control treatment (T1) was conducted using only fresh water.

\section{Chemical composition}

The tomato moisture, ash, fat, crude fiber, reducing sugar $(\%), \mathrm{pH}$ and total titratable acidity (mg of $\mathrm{NaOH} / 100 \mathrm{~g}$ ) were determined according to methodologies described by the Association of Official Analytical Chemists (2010).

\section{Antioxidant Capacity}

Tomato extracts were obtained according to a methodology adapted from Swain and Hillis (1959) and Torres (2002) to determine the antioxidant capacity.

The phenolic content was determined according to the methodology described by Quettier-Deleu et al. (2000) and Singleton and Rossi Jr (1965).

The antioxidant capacity was determined through the methods DPPH (2.2-definil-1picrilidrazil) and Ferric Reducing Antioxidant Power (FRAP) (Rufino et al., 2010). The absorbance was measured using an UV Spectrophotometer (NOVA 2000UV, Nova instruments, São Paulo, Brazil) at $517 \mathrm{~nm}$. The antioxidant capacity was expressed as $\mu \mathrm{M}$ of Trolox Equivalent per $100 \mathrm{~g}$ of sample. All assays were performed with three replications.

\section{Microbiological characteristics}

The microbiological characteristics was accessed according to the Technical Regulation on microbiological standards for foods (BRASIL, 2001). Analyses of coliforms at $45^{\circ} \mathrm{C}$ and salmonella were performed according to the methodologies recommended by the American Public Health Association (VANDERZANT; SPLITTSTOESSER, 1992).

\section{Statistical analysis}

All analyses were performed with three replications and all data were presented as mean values with standard deviations. The results were subjected to analysis of variance and the means were compared by the Tukey test at $5 \%$ of significance.

\section{RESULTS AND DISCUSSION}

\section{Chemical composition of tomatoes}

The composition and physicochemical characteristics of the organic cherry tomatoes, depending on the different rates of nitrogen used are shown in Table 1. According to Warner, Zhang and Hao (2004), nitrogen fertilization acts on physiological processes, affecting important quality properties, such as $\mathrm{pH}$, total soluble solids, titratable acidity, vitamin $\mathrm{C}$ and nitrate contents in tomatoes. Moreover, these physicochemical characteristics are related to sensory attributes important for processed products (e.g. tomato sauce or dehydrated tomatoes), since the product flavor is evaluated mainly by their reducing sugars, total soluble solid and organic acid contents (PICHA, 1987; LIU et al., 2014).

The mean values of moisture $(91.58 \%)$, ash $(0.63 \%)$, fat $(0.875 \%)$ and fiber $(1.50 \%)$ of the cherry tomatoes (Table 1) were similar to those found by Suárez, Rodríguez and Romero (2008) in five cultivars grown under organic system.

The protein content in the cherry tomatoes was affected by the $\% \mathrm{~N}(\mathrm{p}<0.05)$, ranging from 0.89 to $1.13 \%$. The treatments $\mathrm{T} 1$ and $\mathrm{T} 2$ presented the highest protein content $(\mathrm{p}<0.05)$ (Table 1). Protein content is an important parameter, indirectly denoting the presence of important amino acids responsible for the tomato taste and flavor. Glutamate and glutamine are the most abundant free amino acids in ripe cherry tomatoes (CHOI et al., 2014). The glutamate content significant affects the tomato flavor, since the glutamate is responsible for the tomato umami taste (SORREQUIETA et al., 2010; CHOI et al., 2014). According to Rosales et al. (2011), the preference of consumers of tomato fruits is strongly depended on the sweet-acid taste. Thus, the flavor of fresh tomatoes in the market has been taken into account. 
M. F. JORGE et al

Table 1. Composition and physicochemical properties of organic cherry tomatoes.

\begin{tabular}{lcccc}
\hline Analysis (\%) & $\begin{array}{c}\text { Treatment } \\
0 \% \mathrm{~N}\end{array}$ & $\begin{array}{c}\text { Treatment } 2 \\
50 \% \mathrm{~N}\end{array}$ & $\begin{array}{c}\text { Treatment } 3 \\
100 \% \mathrm{~N}\end{array}$ & $\begin{array}{c}\text { Treatment } 4 \\
150 \% \mathrm{~N}\end{array}$ \\
\hline Moisture & $91.48 \pm 0.41 \mathrm{~A}$ & $91.28 \pm 1.04 \mathrm{~A}$ & $92.15 \pm 0.10 \mathrm{~A}$ & $91.40 \pm 0.21 \mathrm{~A}$ \\
Ash & $0.59 \pm 0.10 \mathrm{~A}$ & $0.66 \pm 0.10 \mathrm{~A}$ & $0.60 \pm 0.07 \mathrm{~A}$ & $0.65 \pm 0.14 \mathrm{~A}$ \\
Fat & $0.81 \pm 0.02 \mathrm{~A}$ & $0.95 \pm 0.15 \mathrm{~A}$ & $0.87 \pm 0.03 \mathrm{~A}$ & $0.85 \pm 0.09 \mathrm{~A}$ \\
Protein & $1.13 \pm 0.17 \mathrm{AB}$ & $1.10 \pm 0.11 \mathrm{AB}$ & $0.99 \pm 0.21 \mathrm{~B}$ & $0.89 \pm 0.12 \mathrm{~B}$ \\
Fiber & $1.91 \pm 0.77 \mathrm{~A}$ & $1.68 \pm 0.02 \mathrm{~A}$ & $1.21 \pm 0.49 \mathrm{~A}$ & $1.23 \pm 0.53 \mathrm{~A}$ \\
Acidity $(\mathrm{mg}$ of $\mathrm{NaOH} / 100 \mathrm{~g})$ & $0.62 \pm 0.01 \mathrm{~A}$ & $0.55 \pm 0.05 \mathrm{~A}$ & $0.61 \pm 0.02 \mathrm{~A}$ & $0.54 \pm 0.04 \mathrm{~A}$ \\
Reducing sugars & $4.08 \pm 0.41 \mathrm{~A}$ & $4.33 \pm 0.04 \mathrm{~A}$ & $4.18 \pm 0.08 \mathrm{~A}$ & $4.57 \pm 0.03 \mathrm{~A}$ \\
pH & $4.41 \pm 0.04 \mathrm{~B}$ & $4.45 \pm 0.01 \mathrm{~B}$ & $4.38 \pm 0.01 \mathrm{D}$ & $4.52 \pm 0.01 \mathrm{~A}$ \\
Solids Soluble $\left(\mathrm{Brix}^{\mathrm{o}}\right)$ & $7.20 \pm 0.50 \mathrm{~A}$ & $7.25 \pm 0.10 \mathrm{~A}$ & $7.00 \pm 0.10 \mathrm{~B}$ & $7.00 \pm 0.20 \mathrm{~B}$ \\
\hline
\end{tabular}

Values expressed as mean \pm standard deviation $(n=3)$; means followed by the same letters in the lines does not statistically differ $(\mathrm{p}>0.05)$.

The acidity and reducing sugar content were not affected $(\mathrm{p}>0.05)$ by the $\% \mathrm{~N}$ of the DCW (Table 1). The average acidity value was $0.59 \mathrm{mg}$ of $\mathrm{NaOH}$ per $100 \mathrm{~g}$ of cherry tomatoes. Acidity is an important sensory attribute in cherry tomatoes, followed by simple organic acids, such as the citric and malic (KAPOULAS et al., 2011). In addition, carbohydrates, organic acids and their interactions are important for sweetness, sourness and flavor intensity in tomatoes, thus, they are major determinants of the tomato quality (HELYES et al., 2006; KAPOULAS et al., 2011).

The reducing sugar content of the cherry tomatoes ranged from 4.08 to $4.57 \%$. Tomato fruits accumulate sugars as sucrose or hexoses (glucose and fructose), depending on the environmental conditions and growth stage, which are important for the tomato taste (ROSALES et al., 2011; TURHAN; SENIZ, 2009).

The $\mathrm{pH}$ value and solids soluble ( ${ }^{\circ}$ Brix) were affected by the $\% \mathrm{~N}$ (Table 1$)$. The treatment $\mathrm{T} 4$ had a slightly higher $\mathrm{pH}$ (4.52) than the control (4.41), T2 $(4.45)$ and T3 (4.38) $(\mathrm{p}<0.05)$. Despite the statistical significance, this difference is not biologically relevant. Fruits with $\mathrm{pH}$ values up to 4.5 were classified as acidic and generally considered to have appreciable smell and taste. Pinho et al. (2011) found $\mathrm{pH}$ values of 4.1 and 4.3 for organic cherry tomatoes in different harvesting times, and Guilherme et al. (2014) found $\mathrm{pH}$ ranging from 4.41 to 4.61 in three genotypes of organic cherry tomatoes.

The cherry tomatoes presented soluble solid (SS) contents (Table 1) higher than those found by Aldrich et al. (2010) (3.52 to $4.82{ }^{\circ}$ Brix) in ten cultivars of organic tomatoes, and Kapoulas et al. (2011), who found an average value of $4.73^{\circ}$ Brix in the organic tomatoes varieties Robin-F1, Amati-F1 and Elpida-F1.

The control and $\mathrm{T} 2(50 \% \mathrm{~N})$ treatments showed higher $(\mathrm{p}<0.05)$ solids soluble contents than the T3 and T4 (Table 1). These results were similar to those found by May and Gonzales (1994), who observed an increase in solids soluble percentages from 5.25 to $5.4 \%$ with a decrease in $\mathrm{N}$-fertilization rate from 392 to $168 \mathrm{~kg} \mathrm{~N} \mathrm{ha}^{-1}$.

\section{Antioxidant capacity and total phenolic compounds}

The different $\mathrm{N}$ rates applied to the organic cherry tomatoes significantly affected $(p<0.05)$ their antioxidant capacity and total phenolic compounds (Table 2). The treatment T4 $(150 \% \mathrm{~N})$ showed the highest values $(p<0.05)$ of antioxidant capacity by the DPPH method and total phenolic compounds, followed by the T3 $(100 \% \mathrm{~N}), \mathrm{T} 2(50 \% \mathrm{~N})$ and $\mathrm{T} 1$ (control $0 \% \mathrm{~N}$ ) (Table 2). This result suggests that a higher $\% \mathrm{~N}$ provides an increase in the antioxidant capacity and phenolic compounds. Bérnard et al. (2009) found a reduced phenolic content for tomatoes cultivated with a decreased nitrogen concentration.

However, the control treatment (T1) showed the highest antioxidant capacity by the FRAP method, followed by the T2, T3 and T4 (Table 2).

Toor, Savage and Heeb (2006) reported that fertilizer sources can have significant effects on macronutrient concentration, taste and antioxidant components of tomatoes. Moreover, tomato fruits are rich in polyphenols, which are responsible for the antioxidant capacity of the soluble phase. Thermal stress induces the accumulation of phenolic compounds, such as flavonoids and phenylpropanoids (HELYES et al., 2006). 
M. F. JORGE et al

Table 2. Antioxidant capacity and total phenolic compounds of organic cherry tomatoes.

\begin{tabular}{lcccc}
\hline Analysis (\%) & Treatment 1 & Treatment 2 & Treatment 3 \\
$0 \% \mathrm{~N}$ & $50 \% \mathrm{~N}$ & $100 \% \mathrm{~N}$ & $\begin{array}{c}\text { Treatment } 4 \\
150 \% \mathrm{~N}\end{array}$ \\
\hline Antioxidant capacity (DPPH) & $5.29 \pm 0.01 \mathrm{C}$ & $7.37 \pm 0.10 \mathrm{~B}$ & $7.43 \pm 0.05 \mathrm{~B}$ & $7.65 \pm 0.02 \mathrm{~A}$ \\
Antioxidant capacity (FRAP) & $966.66 \pm 0.04 \mathrm{~A}$ & $860.34 \pm 0.03 \mathrm{~B}$ & $845.97 \pm 0.12 \mathrm{C}$ & $842.41 \pm 0.07 \mathrm{C}$ \\
Total Phenolic Compounds & $846.25 \pm 0.04 \mathrm{C}$ & $846.11 \pm 0.02 \mathrm{C}$ & $941.14 \pm 0.03 \mathrm{~B}$ & $1022.86 \pm 0.01 \mathrm{~A}$ \\
\hline
\end{tabular}

Analyzes performed with three replications (dry basis). Values are expressed as mean \pm standard deviation. Means followed by the same letters in the rows do not differ significantly ( $>0.05$ ) by the Tukey's test. DPPH (2.2-definil-1picrilidrazil) values are expressed as $\mu \mathrm{M}$ equivalent to Trolox $\mathrm{g}^{-1}$ of the sample; and FRAP (Ferric Reducing Antioxidant Power) values are expressed as $\mathrm{mg} \mathrm{mL}^{-1}$ of the solution, equivalent to $1000 \mu \mathrm{M}$ of Ferrous Sulfate; Total phenolic compounds are expressed in $\mathrm{mg} 100 \mathrm{~g}^{-1}$ gallic acid.

The treatments $\mathrm{T} 1$ and $\mathrm{T} 2$ showed the highest values of total phenolic compounds (Table 2). The leaf polyphenol content of young greenhouse tomato plants increases considerably with low $\mathrm{N}$ availability (STOUT; BROVONT; DUFFEY, 1998; DUMAS et al., 2003). However, Dumas et al. (2003) reported that no information about the effects of fertilizers on the production of phenolic substances in tomato is found in the literature. According to Borguini et al. (2013), phenolic compounds are formed by the secondary metabolism of plants. Many secondary metabolites act as fungicides and antibiotics to protect plants from fungi and bacteria. Thus, organic foods have high contents of phenolic compounds because of the possible incidence of pests and pathogens in this cultivation method, in which pesticides are not used. These incidences may cause some stress to plants and, therefore, increase the phenolic compounds production as natural defenses.

\section{Microbiological quality}

The different concentrations of $\mathrm{N}$ did not affect the microbiological quality of the tomatoes, suggesting that there was no growth of microorganisms that causes risks to the health of consumers of organic products in these tomatoes. Tomatoes from all treatments showed fecal coliforms count $<3 \mathrm{MPN} \mathrm{g}^{-1}$ and absence of salmonella in $25 \mathrm{~g}$, therefore, they were in accordance with the Brazilian Legislation (RDC 12) (BRASIL, 2001). According to Arbos (2010), the risk of food contamination is not related to the use of dairy cattle wastewater, but to contaminated soil or irrigation, presence of animals and inadequate use of composting.

\section{CONCLUSION}

The different percentages of nitrogen of the dairy cattle wastewater affected the physicochemical characteristics, however, it did not affect the microbiological characteristics of the tomatoes, which presented fecal coliforms count $<3 \mathrm{MPN} \mathrm{g}^{-1}$ and absence of Salmonella in $25 \mathrm{~g}$ in all samples.

The cherry tomatoes presented significant antioxidant capacity, with the treatments T3 $(100 \%$ $\mathrm{N})$ and T4 $(150 \% \mathrm{~N})$ presenting the highest values of antioxidant capacity (DPPH) and total phenolic compounds. On the other hand, T1 (untreated samples) presented the highest antioxidant capacity by the FRAP method.

\section{ACKNOWELEDGMENTS}

The authors thank the FAPERJ for financial support; the CAPES for granting the doctoral scholarship of the first author; the MEC/PROEXT 2011/2012 for providing the equipment Pro-2010 and 2012 .

\section{REFERENCE}

ABDEL-MONAIM, M. F., et al. Effect of chemical inducers on root rot and wilt diseases, yield and quality of tomato. International Journal of Agricultural Sciences, Brooklyn, v. 2, n. 2, p. 2011 2020, 2012.

AGRAWAL, M.; SINGH, A. Reduction in metal toxicity by applying different soil amendments in agricultural field and its consequent effects on characteristics of radish plants (Raphanus sativus L.). Journal of Agricultural Science and Technology, Tehran, v. 15, n. 1, p. 1553-1564, 2013.

ALDRICH, H. T. et al. Cultivar choice provides options for local production of organic and conventionally produced tomatoes with higher quality and antioxidant content. Journal of the Science of Food and Agriculture, Nova York, v. 90 , n. 15 , p. $2548-2555,2010$.

ALVES, S. M. C. et al. Balanço do nitrogênio e fósforo em solo com cultivo orgânico de hortaliças após a incorporação de biomassa de guandu. Pesquisa Agropecuária Brasileira, Brasília, v. 39, n. 11, p. 1111-1117, 2004. 
ARBOS, K. A. et al. Segurança alimentar de hortaliças orgânicas: aspectos sanitários e nutricionais. Ciência e Tecnologia de Alimentos, Campinas, v. 30, Sup., p. 215-220, 2010.

Association of Official Analytical Chemists (AOAC). (2010). Official methods of analysis of AOAC International. 18 ed., $3^{\mathrm{a}}$ rev, 2010.

BÉNARD, C. et al. Effects of low nitrogen supply on tomato (Solanum lycopersicum L.) fruit yield and quality with special emphasis on sugars, acids, ascorbate, carotenoids, and phenolic compounds. Journal of Agricultural and Food Chemistry, Washington, v. 57, n. 10, p. 4112-4123, 2009.

BORGUINI, R. G. et al., Antioxidant potential of tomatoes cultivated in organic and conventional systems. Brazilian Archives of Biology and Technology, Curitiba, v. 56, n. 4, p. 521-529, 2013.

BRASIL, Ministério da Saúde, Agência Nacional de Vigilância Sanitária, Resolução RDC. $n^{0}$ 12, de 02 Janeiro de 2001. Aprova regulamento técnico sobre padrões microbiológicos para alimentos. Diário Oficial da República Federativa do Brasil, Brasília, 02 de janeiro 2001. Disponível em: <http:// www.anvisa.gov.br/e-legis/>. Acessado em: 20 mai. 2015.

BRASIL, Ministério da Agricultura e Abastecimento. Lei $\mathrm{N}^{\circ} 10831$, de 23 de dezembro de 2003- Dispõe sobre a agricultura orgânica e dá outras providências. Disponível em: < http:// www.planalto.gov.br/ccivil_03/leis/2003/

L10.831.htm>. Acesso em: 11 out. 2010.

CARBONARO, M. et al. Modulation of Antioxidant Compounds in Organic vs Conventional Fruit (Peach, Prunus persica L., and Pear, Pyrus communis L.). Journal of Agricultural and Food Chemistry, Washington ,v. 50, n. 19, p. 5458-5462, 2002.

CHAUHAN, H. et al. Novel plant growth promoting rhizobacteria-Prospects and potential. Applied Soil Ecology, Amsterdam, v. 95, n. 1, p. 38-53, 2015.

CHRISTOU, A. et al. Impact assessment of the reuse of two discrete treated wastewaters for the irrigation of tomato crop on the soil geochemical properties, fruit safety and crop productivity. Agriculture, Ecosystems \& Environment, Amsterdam, v. 192, n. 1, p. 105-114, 2014.

CHOI, S. H., et al. Protein, free amino acid, phenolic, $\beta$-carotene, and lycopene content, and antioxidative and cancer cell inhibitory effects of 12 greenhouse-grown commercial cherry tomato varieties. Journal of Food Composition and
Analysis, Amsterdam, v. 34, n. 2, p. 115-127, 2014.

DUMAS, Y.; et al. Effects of environmental factors and agricultural techniques on antioxidant content of tomatoes. Journal of Science and Food Agriculture, Nova York, v. 83, n. 5, p. 369-382, 2003.

ERTHAL, V. J. T. et al. Alterações físicas e químicas de um Argissolo pela aplicação de água residuária de bovinocultura. Revista Brasileira de Engenharia Agrícola e Ambiental, Campina Grande, v. 14, n. 5, p. 467-477, 2010.

FAOSTAT. (2012). Agricultural data (last updated August, 2010-2012). Food and Agriculture Organization of the United Nations. Available from: http://faostat.fao.org/site/339/default.aspx. [Available: Aug 19 2012].

FERRARI, A. A., et al. Chemical composition of tomato seeds affected by conventional and organic production systems. Journal of Radioanalytical and Nuclear Chemistry, London, v. 278, n. 2, p. 399-402, 2008.

FIGÀS, M. R. et al. Characterization of composition traits related to organoleptic and functional quality for the differentiation, selection and enhancement of local varieties of tomato from different cultivar groups. Food chemistry, Amsterdam, v. 187, n. 1, p. 517-524, 2015.

GUILHERME, D. O. et al. Análise sensorial e físico-química de frutos tomate cereja orgânico. Revista Caatinga, Mossoró, v. 27, n. 1, p. 181-186, 2014.

HELYES, L. et al. Effect of maturity stage on content, color and quality of tomato (Lycopersicon lycopersicum (L.) Karsten) fruit. International Journal of Horticultural Science, Budapest, v. 12, n. 1, p. 41-44, 2006.

KAPOULAS, N. et al. Effect of organic and conventional production practices on nutritional value and antioxidant activity of tomatoes. African Journal of Biotechnology, Nairobi, v. 10, n. 71, p. 15938-15945, 2011.

LIAO, Y. et al. Document Increase in soil organic carbon by agricultural intensification in northern China. Biogeosciences, Alberta, v. 12, n. 5, p. 1403 $1413,2015$.

LIU, T. et al. Growth, yield and quality of spring tomato and physicochemical properties of medium in a tomato/garlic intercropping system under plastic tunnel organic medium cultivation. Scientia Horticulturae, Amsterdam, v. 170, n. 1, p. 159-168, 
2014.

NKOA, R. Agricultural benefits and environmental risks of soil fertilization with anaerobic digestates: A review. Agronomy for Sustainable Development, London, v. 34, n. 2, p. 473-492, 2014.

PICHA, D. H. Sugar and organic acid content of cherry tomato fruit at different ripening stages. HortScience, Alexandria, v. 22, n.1, p. 94-96, 1987.

QUETTIER-DELEU, C. et al. Phenolic compounds and antioxidant activities of buckwheat (Fagopyrum esculentum Moench) hulls and flour. Journal of Ethnopharmacology, Amsterdam, v. 72, n. 1, p. 35-42, 2000.

ROCHA, M. C., et al. Descritores quantitativos na determinação da divergência genética entre acessos de tomateiro do grupo cereja. Revista Ciência Rural, Santa Maria, v. 39, n. 3, p. 664-670, 2009.

ROSALES, M. A. et al. The effect of environmental conditions on nutritional quality of cherry tomato fruits: evaluation of two experimental Mediterranean greenhouses. Journal of the Science of Food and Agriculture, Nova York, v. 91, n. 1, p. 152-162, 2011.

RUFINO, M. S. M. et al. Bioactive compounds and antioxidant capacities of 18 non-traditional tropical fruits from Brazil. Food chemistry, Amterdam, v. 121, n. 4, p. 996-1002, 2010.

PINHO, L. et al. Nutritional properties of cherry tomatoes harvested at different times and grown in an organic cropping. Horticultura Brasileira, Brasília, v. 29, n. 2, p. 205-211, 2011.

SILVA, A. C., et al. Avaliação de linhagens de tomate cereja tolerantes ao calor sob sistema orgânico de produção. Revista Caatinga, Mossoró, v. 24, n. 3, p. 33-40, 2011.

SINGH, H. et al. Evaluation of Total Phenolic Compounds and Insecticidal and Antioxidant Activities of Tomato Hairy Root Extract. Journal of Agriculture and Food Chemistry, Washington, v. 62, n. 12, p. $2588-2594,2014$.

SINGLETON, V. L.; ROSSI JR, J. A. Colorimetry of total phenolics with phosphomolybdicphosphotungstic acid reagents. American Journal of Enology and Viticulture, Davis, v. 16, n. 3, p. 144-158, 1965.

SORREQUIETA, A. et al. Free amino acid production during tomato fruit ripening: a focus on L-glutamate. Amino Acids, London, v. 38, n. 5, p. 1523-1532, 2010.
STOUT, M. J.; BROVONT, R. A.; DUFFEY, S. S. Effect of nitrogen availability on expression of constitutive and inducible chemical defenses in tomato, Lycopersicon esculentum. Journal of Chemical Ecology, London, v. 24, n. 6, p. 945-963, 1998.

SUÁREZ, M. H.; RODRÍGUEZ, E. R.; ROMERO, C. D. Analysis of organic acid content in cultivars of tomato harvested in Tenerife. European Food Research and Technology, London, v. 226, n. 3, p. 423-435, 2008.

SWAIN, T.; HILLIS, W. E. The phenolic constituents of prunus domestica. The quantitative analysis of phenolic constituents. Journal of the Science of Food and Agriculture, Nova York, v. 10, n. 1, p. 63-68, 1959.

TOOR, R. K.; SAVAGE, G. P.; HEEB, A. Influence of different types of fertilizers on the major antioxidant components of tomatoes. Journal of Food Composition and Analysis, Amsterdam, v. 19, n. 1, p. 20-27, 2006.

TORRES, D. E. G. et al. Antioxidant activity of macambo (Theobroma bicolor L.) extracts. European Journal of Lipid Science and Technology, Nova York, v. 104, n. 1, p. 278-281, 2002.

TURHAN, A.; SENIZ, V. Estimation of certain chemical constituents of fruits of selected tomato genotypes grown in Turkey. African Journal of Agricultural Research, Nairobi, v. 4, n. 10, p. 1086-1092, 2009.

VANDERZANT, C.; SPLITTSTOESSER, D. F. Compendium of methods for the microbiological examination of foods. Washington: American Public Health Association, 1992. 1219 p.

WARNER, J.; ZHANG, T. Q.; HAO, X. Effects of nitrogen fertilization on fruit yield and quality of processing tomatoes. Canadian Journal of Plant Science, Ottawa, v. 84, n. 3, p. 865-861, 2004. 